\title{
Accumulation and Translocation of Chromium (Cr) and Lead (Pb) in Chilli Plants (Capsicum annuum L.) Grown on Artificially Contaminated Soil
}

\author{
F. Ahmed*†, A. N. M. Fakhruddin**, Z. Fardous***, M. A. Z. Chowdhury***, M. M. Rahman*** \\ and M. M. Kabir**** \\ *Department of Environmental Science, Bangladesh University of Professionals, Mirpur Cantonment, Dhaka, \\ Bangladesh \\ **Department of Environmental Sciences, Jahangirnagar University, Savar, Dhaka 1342, Bangladesh \\ ***Agro-chemical and Environmental Research Division, Institute of Food and Radiation Biology, Atomic Energy \\ Research Establishment, Savar, Dhaka 1349, Bangladesh \\ ****Department of Environmental Science and Disaster Management, Noakhali Science and Technology University, \\ Noakhali-3814, Bangladesh \\ $†$ Corresponding author: F. Ahmed; fowzia.ahmed@ bup.edu.bd
}

Nat. Env. \& Poll. Tech.

Website: www.neptjournal.com

Received: 15-06-2020

Revised: $18-09-2020$

Accepted: 09-10-2020

Key Words:

Chromium

Lead

Health risk index

Carcinogenic risks

Capsicum annuum L.

\begin{abstract}
The current study is an endeavour to measure the bioaccumulation potentials of heavy metals in different parts of chilli plants (Capsicum annuum L.) grown in artificially contaminated soil with various concentrations of $\mathrm{Cr}$ and $\mathrm{Pb}$. The concentrations of heavy metals were estimated by Atomic Absorption Spectroscopy (AAS) technique. The mean concentration of $\mathrm{Cr}$ and $\mathrm{Pb}$ accumulated in different parts of plants in high, medium, and low levels of contamination was in the following order: roots > leaves $>$ shoots > fruits. Cr concentration in fruits was lower than that of the WHO standard. However, fruits grown on medium contaminated soil contained $0.695 \mathrm{mg} / \mathrm{kg} \mathrm{Cr}$ which did not follow the safe guideline by SEPA. A significant amount of $\mathrm{Pb}$ was traced in fruits grown in highly contaminated soil that exceeded the standard limit set by $\mathrm{FAO} / \mathrm{WHO}$. Accumulation of $\mathrm{Pb}$ was higher than $\mathrm{Cr}$ at different levels of contamination in every part of the chilli plants. The transfer factor for $\mathrm{Cr}$ and $\mathrm{Pd}$ was found in the following order, leaves $>$ shoots $>$ fruits $>$ roots and leaves $>$ shoots $>$ roots $>$ fruits, correspondingly at every level of contamination. The bioconcentration factors were higher in $\mathrm{Pb}$ than $\mathrm{Cr}$. The daily intake of metals in combination with health and carcinogenic risk indexes indicated that the edible parts of chilli plants are safe to consume as recommended by SEPA/WHO/FAO. The present study can be considered a reference for assessment and monitoring of heavy metals associated with human health risks in chilli plants at different industrially contaminated sites.
\end{abstract}

\section{INTRODUCTION}

Since the enhancement of industrialization, heavy metal pollution in soil and water has become a widespread phenomenon that can pose a threat to human and biotic life. Because of low biodegradability, heavy metals accumulate in the soil adjacent to industrial areas. Crops grown in contaminated soil can accumulate heavy metals in their edible parts and cause serious health issues to both human and animal consumers (Sarma et al. 2011). Not only human health but also plants are affected by heavy metal contamination in many ways. Plant growth, seed germination, metabolism, chlorophyll content, etc. are affected by heavy metal pollution in the soil (Pandey \& Sharma 2002, Aydinalp \& Marinova 2009). Contamination of toxic heavy metals has been rapidly spreading in the crop fields of Bangladesh. Due to industrial development, some of the regions of Bangladesh such as Gazipur,
Savar, Narayanganj (Hossain et al. 2015), Tangail (Proshad et al. 2019), etc. are getting highly polluted by the contamination of heavy metals. Buriganga, Sitalakhya and Turag are some of the polluted rivers around Dhaka city. Heavy metals dissolved in industrial water are severely polluting the sediments of these rivers. A high concentration of heavy metals has been found in different crops of Bangladesh, for example, paddy (Halim et al. 2014), vegetables (Naser et al. 2012), spices (Gleason et al. 2014), etc. Heavy metals enter into the human body through the consumption of the edible parts of these plants. Although some metals are necessary for biochemical and physiological functions, a good number of them cause numerous complications in human health. The nervous system, kidney, liver and other organs of the human body suffer from cancer and other complicated diseases as a result of heavy metal consumption (Karbassi et al. 2018). 
Chilli (Capsicum annuum L.) is one of the most popular spices in Bangladesh. The use of chilli is found indispensable in the preparation of dishes ranging from green salad to red curries. Chillies have been a part of the regular human diet in Bangladesh (BBS 2015). The chilli belongs to the Solanaceae family, having a variety of names depending on its production location and type. Chillies are small in size and widely used as spices for their sharp, acidic flavour and colour (BBS 2015). A significant amount of vitamins A and $\mathrm{C}$ are found in chillies which are essential for human health. Chillies also contain a wide variety of minerals such as potassium, magnesium and iron. Like other vegetables of Solanaceae family, the chilli plant accumulates and translocates heavy metals from soil to its fruits (Guertin 2004). Heavy metals can accumulate in the root, shoot, and fruits of chilli at its different growth stages. Among the heavy metals, $\mathrm{Cr}$ and $\mathrm{Pb}$ and their compounds are widely used in the industrial sectors. Chromium (VI) consumption may cause adverse gastrointestinal effects, including abdominal pain, vomiting, gastrointestinal ulceration, haemorrhage and necrosis, and bloody diarrhoea (Guertin 2004, Kabir et al. 2017, Kabir et al. 2018). Consumption of lead is also lethal for human health; it is six-times toxic than absorbed by the skin. Repetitive consumption of lead and chromium through food like chilli may cause a serious health impact on human (Akintan et al. 2019).

This study aims to determine the accumulation and translocation of $\mathrm{Cr}$ and $\mathrm{Pb}$ in different parts of chilli plants (roots, shoots, leaves, and fruits) grown in artificially contaminated soil with various concentrations of $\mathrm{Cr}$ and $\mathrm{Pb}$ which is the first of its kind, so far, reporting bioaccumulation potentials of chilli plants. This study will be a baseline for future environmental contaminant's human health risk identification in chilli plants at the field level of Bangladesh.

\section{MATERIALS AND METHODS}

\section{Soil Preparation}

The soil sample was collected from the arable horizon (0-30 cm depth) of the Botanical garden of Jahangirnagar University, Dhaka. The soil was mixed with cow dung as an amendment. Under room temperature, the soil was airdried, cleansed to remove grass and dirt, and ground. Every $4 \mathrm{~L}$ of plastic pot was filled with $3 \mathrm{~kg}$ of soil, which was sprayed with different concentrations of chromium $(\mathrm{Cr})$ and lead $(\mathrm{Pb})$. The stock solutions of varying levels of $\mathrm{Cr}$ and $\mathrm{Pb}$ were prepared by $\mathrm{K}_{2} \mathrm{Cr}_{2} \mathrm{O}_{7}$ and $\mathrm{Pb}\left(\mathrm{NO}_{3}\right)_{2}$, respectively, and sprayed onto the soil samples with continuous mixing to homogenize the distribution of the applied heavy metals. Four levels $(0,100,200$ and $400 \mathrm{mg} / \mathrm{kg}$ soil) of $\mathrm{Cr}$ and $\mathrm{Pb}$ such as unadulterated, low, medium and high levels respectively were sprayed distinctly in soil with three replicates. The spiked soils were allowed to be air-dried for one hour.

\section{Soil Sample Preparation and Digestion}

With the addition of concentrated $\mathrm{HNO}_{3}$ acid and concentrated $\mathrm{HClO}_{4}$ acid, soil samples were digested for heavy metal determination (Allen et al. 1986). One g of homogenized composite soil sample was taken into the clean beaker, and $10 \mathrm{~mL}$ of $65 \%$ concentrated $\mathrm{HNO}_{3}$ acid and $5 \mathrm{~mL}$ of $70 \%$ concentrated $\mathrm{HClO}_{4}$ acid were added to it. Then the mixture was heated in a hot plate at different temperatures up to dryness in a fume chamber. After cooling it down, the beaker was washed with distilled water, and the mixture was transferred into a volumetric flask to make the volume to $50 \mathrm{~mL}$. Then the solution was filtered into a plastic bottle through Whatman No. 1 and finally taken for heavy metals determination by Atomic Absorption Spectroscopy (AAS).

\section{Quality Control and Quality Assurance}

Quality control and quality assurance have been integrated into this study. Representative standards of the heavy metals ( $\mathrm{Cr}$ and $\mathrm{Pb}$ ) at four different levels (0, 100, 200 and $400 \mathrm{ppm}$ ) were spiked into the soil free of heavy metals. The mixed soil was allowed to be air-dried for one hour. After that, it was analysed according to the following procedure (Chowdhury et al. 2013). By using the following equation, the percentage of recovery was calculated.

$$
\text { Percentage recovery }=(\mathrm{CE} / \mathrm{CM} \times 100)
$$

Where, $\mathrm{CE}$ is the experimental concentration and $\mathrm{CM}$ is the spiked concentration.

Percentage recoveries of the tested metals in soil samples were $77.5 \%$ to $91.84 \%$ (Table 1). According to the European Commission, the data between $70 \%-110 \%$ indicate that the method is accurate and precise.

Table 1: The percentage of recoveries of tested metals from soil samples.

\begin{tabular}{|lllll|}
\hline Heavy Metals & \multicolumn{4}{l}{ Concentration $(\mathrm{mg} / \mathrm{kg})$} \\
\cline { 2 - 5 } & & Spiked & Measured & Recovery $\%$ \\
\hline Chromium (Cr) & Control & 0.00 & 1.148 & - \\
& Sample-1 & 400 & 310.275 & $77.5 \%$ \\
& Sample-2 & 200 & 169.274 & $84.64 \%$ \\
& Sample-3 & 100 & 87.512 & $87.50 \%$ \\
Lead (Pd) & Control & 0.00 & 0.186 & - \\
& Sample-1 & 400 & 318.657 & $79.66 \%$ \\
& Sample-2 & 200 & 168.978 & $84.49 \%$ \\
& Sample-3 & 100 & 91.847 & $91.84 \%$ \\
\hline
\end{tabular}




\section{Growth of Chilli (Capsicum annuum) Plants in Artificially Contaminated Soil}

Chilli (black cobra peepers) plant saplings were collected from a nursery nearby Jahangirnagar University. They were about 4-5 inches in height and planted in the artificially contaminated soil. Plants were irrigated with tap water and allowed to grow until fruits came out. For the blank sample, four levels of $\mathrm{Cr}$ and $\mathrm{Pb}(0,100,200$ and $400 \mathrm{mg} / \mathrm{kg}$ soil) contaminated soil with three replicates remain kept without any plant.

\section{Plant Material Digestion}

Different parts of chilli plants were collected and washed in distilled water. All the parts of the plants were oven-dried. Then they were crushed with a mortar and stored in a plastic container. The powdered samples were placed into the crucible, to which $10 \mathrm{~mL}$ of $65 \%$ concentrated $\mathrm{HNO}_{3}$ acid and 5 $\mathrm{mL}$ of $70 \%$ concentrated $\mathrm{HClO}_{4}$ acid were added. Then the mixture was heated in a hotplate at different temperatures up to dryness in a fume chamber. Then, samples were cooled and filtered through Whatman No. 1 filter paper. The volume of the residues was made up to $50 \mathrm{~mL}$. Finally, the solution was ready for analysis.

\section{Determination of Heavy Metal Concentrations of Soil and Plant Samples}

Atomic Absorption Spectroscopy (AAS) (Model: AA-6300, Atomic Absorption Flame Spectrophotometer, SHIMADZU, Japan) was used for the determination of heavy metals as described by Allen et al. (1986).

\section{Transfer Factor (TF)}

The transfer factor was calculated to determine the translocation of heavy metals from soil to different parts of the plants (Lawrence \& Borkowsky 1983). To determine the transfer factor, the concentration of heavy metals in the root of Capsicum annuum was divided by the total heavy metal concentrations in soil. Transfer of heavy metals from root to shoot, shoot to leaves, and leaves to fruit was also determined by using the following equation.

$$
\mathrm{TF}=\frac{\text { Concentrationofmetalin root }}{\text { Concentrationofmetalin soil }}
$$

\section{Bioconcentration Factor (BCF)}

The BCF of metal is an index that determines a plant's capacity to accumulate a specific metal regarding its concentration in the soil. It is a valuable indicator of the bioaccumulation potential of a substance. BCF was calculated by determining the ratio of the concentration of a metal in a plant to the concentration in the soil. The equation is given below.
$B C F=\frac{\text { Metal concentration in plant tissue }(\text { whole plant })}{\text { Initial concentration of metal in substrate }(\text { soil })} \ldots$

The high BCF value indicates the more suitability of plant for phytoextraction (Mackay 1982).

\section{Daily Intake of Heavy Metals (DIM)}

The daily intake of heavy metals was calculated by the multiplication of the concentration of heavy metals in vegetables with conversion factors and daily intake of vegetables. Then, this value was divided by the average body weight. The determination of DIM value was calculated according to the following equation (Khan et al. 2009).

$$
\mathrm{DIM}=\mathrm{C}_{\text {metal }} \times \mathrm{C}_{\text {factor }} \times \mathrm{F}_{\text {oodintake }} / \mathrm{B} \text { average weigh }
$$

Where, $\mathrm{M}_{\text {etal }}=$ heavy metals concentration in vegetables $(\mathrm{mg} / \mathrm{kg}), \mathrm{C}_{\text {factor }}=$ conversion factor of $0.085, \mathrm{~F}_{\text {ood intake }}=$ daily intake of vegetables $(\mathrm{kg} / \mathrm{day})$ and $\mathrm{B}_{\text {average weight }}=$ average body weight, $\mathrm{kg}$. An estimated value of the daily intake of chilli is $15 \mathrm{~g}$ per day per person, and the average weight is $60 \mathrm{~kg}$.

\section{Health Risk Index (HRI)}

The health risk index of $\mathrm{Cr}$ and $\mathrm{Pb}$ by consumption of contaminated chilli was estimated by dividing the DIM to oral reference dose RfD values.

$$
\mathrm{HRI}=\mathrm{DIM} / \mathrm{RfD}
$$

$\mathrm{R}_{\mathrm{f}} \mathrm{D}$ is the USEPA's highest tolerable oral dose of a lethal substance.

In this study, the oral reference dose values for $\mathrm{Cr}(0.003$ $\mathrm{mg} \mathrm{kg}^{-1}$ per day) and $\mathrm{Pb}\left(0.0035 \mathrm{mg} \mathrm{kg}^{-1}\right.$ per day $)$ were considered as described by WHO (1993). The safe health risk index for the exposed population is not more than 1 (Tsafe et al. 2012).

\section{Carcinogenic Risk (CR)}

Carcinogenic risk (CR) is an index which determines the risk of cancer. It can be calculated by using the following equation, which was modified from Shaheen et al. (2016).

$$
\mathrm{CR}=\mathrm{DIM} / \mathrm{CSF}
$$

Here, CSFo is the oral carcinogenic slope factor, which was $0.0085 \mathrm{mg} / \mathrm{kg} /$ day for $\mathrm{Pb}$ and $0.041 \mathrm{mg} / \mathrm{kg} /$ day for As (USEPA 2017).

\section{RESULTS AND DISCUSSION}

\section{Effects on Chilli Plants Grown in Artificially Contaminated Soil by $\mathrm{Cr}$ and $\mathrm{Pb}$}

Consumption and distribution of total chromium and lead (mg/ $\mathrm{kg}$ ) in different parts of chilli (Capsicum annuиm L.) plants have been illustrated in Table 2. By evaluating the similarities 
with control, all parts of the chilli plant accumulated $\mathrm{Cr}$ and $\mathrm{Pb}$. Roots exhibit the highest concentration of both $\mathrm{Cr}$ and $\mathrm{Pb}$ at high, medium and low levels of contamination. Leaves accumulated a significant amount of chromium and lead than shoot, and translocation from shoot to leaves was higher than any other parts of the plants. Moreover, in the case of both metals, translocation from soil to fruit was not so high. The average concentration of chromium and lead in different parts of chilli plants in high, medium, and low levels of contaminations were found to decrease in the order of roots $>$ leaves $>$ shoots $>$ fruits.

Table 3 represents the safe limit of heavy metal concentration in vegetables $(\mathrm{mg} / \mathrm{kg})$ which indicated that the $\mathrm{Cr}$ concentrations in fruits were found much lower compared to the WHO standard. However, fruits of medium contamination $(0.695 \pm 0.151 \mathrm{mg} / \mathrm{kg})$ slightly exceeded the safe limit of 0.5 $\mathrm{mg} / \mathrm{kg}$ given by USEPA 2005. At a low contamination level, the chilli plant accumulated only $0.248 \pm 0.156 \mathrm{mg} / \mathrm{kg}$ of $\mathrm{Cr}$. In this study, $\mathrm{Cr}$ did not yield any fruits at a high level of contamination. The plant growth was considerably hampered because of the high concentration of $\mathrm{Cr}$. Growth reduction and biomass accumulation had been caused due to the high toxicity of $\mathrm{Cr}$ (Iqbal et al. 2001). Photosynthesis, respiration, water and minerals intake mechanisms are significantly disturbed by Cr accumulation (Dube et al. 2003). Accumulation of $\mathrm{Cr}$ is responsible for the reduction of starch and nitrogen metabolism. It can directly influence the enzyme activity or production of reactive oxygen species (Singh et al. 2013). Mellem et al. (2009) examined a similar study on translocation and accumulation of $\mathrm{Cr}$ in Amaranthus dubious and reported that $\mathrm{Cr}$ is stored in the roots of plants, and a few of them translocate to the aerial parts too. Similar results have been observed in the current study suggesting the roots of the chilli plant accumulated more $\mathrm{Cr}$ than other parts. Fruits did not exceed the safe limit of $\mathrm{Pb}$ accumulation, according to both FAO/WHO (1985) and USEPA (2005) (Table 3).

However, fruits of high contamination exceeded the safe limit of $0.3 \mathrm{mg} / \mathrm{kg}$ given by FAO/WHO (2001). Lead $(\mathrm{Pb})$ accumulation in the medium and low level of contamination was found $0.881 \pm 0.410 \mathrm{mg} / \mathrm{kg}$ and $0.530 \pm 0.139 \mathrm{mg} / \mathrm{kg}$, respectively. According to Lima et al. (2009), Pb accumulation in different parts of vegetable plants was found in the following order, root $>$ stems $>$ leaves $>$ edible parts where the plants were grown on the soil contaminated by battery recycling waste. However, the current study shows the order of leaves $>$ shoots $>$ fruits for $\mathrm{Pb}$ accumulation. $\mathrm{Pb}$ and $\mathrm{Ni}$ accumulation were found in the greatest concentration in Cauliflower and cabbage (Singh et al. 2012). Gupta et al.(2007) reported a diverse variety of vegetables grown on exaggeratedly contaminated soil and all the vegetables accumulated heavy metals $(\mathrm{Pb}, \mathrm{Zn}, \mathrm{Cd}, \mathrm{Cr}$ and $\mathrm{Ni}$ ) which concentrations exceeded the safe limits. Hung et al. (2014), investigated a similar study and found that roots of the okra plant (Abelmoschus esculentus) accumulated more lead then the leaves and fruits, which is similar to the current study.

\section{Comparison Between Accumulation of $\mathrm{Cr}$ and $\mathrm{Pb}$ in Different Parts of Chilli Plants}

In the body of the plants, accumulation varies from metal to metal. There are both similarities and differences in the accumulation of $\mathrm{Cr}$ and $\mathrm{Pb}$ in the plants. The similarity between elemental distribution appeared in both metals and was found in the decreasing order: roots $>$ leaves $>$ shoot $>$ fruits. At every level of contamination, the accumulation of $\mathrm{Pb}$ was higher than $\mathrm{Cr}$ in every part of the chilli plants. At high concentration, accumulations of $\mathrm{Pb}$ in roots were two

Table 2: Uptake and distribution of total chromium $(\mathrm{mg} / \mathrm{kg})$ and lead $(\mathrm{mg} / \mathrm{kg})$ in different parts of chilli plant.

\begin{tabular}{|c|c|c|c|c|c|}
\hline \multirow[t]{2}{*}{ Level of contamination } & \multicolumn{5}{|c|}{ Average Concentration of $\mathrm{Cr}(\mathrm{mg} / \mathrm{kg})$} \\
\hline & Soil & Roots & Shoots & Leaves & Fruits \\
\hline Control & $1.489 \pm 0.441$ & $0.165 \pm 0.035$ & $0.087 \pm 0.022$ & $0.094 \pm 0.018$ & $0.048 \pm 0.013$ \\
\hline High & $65.448 \pm 6.136$ & $7.932 \pm 1.40$ & $2.780 \pm 0.303$ & $3.013 \pm 0.749$ & NA \\
\hline Medium & $31.088 \pm 2.093$ & $5.906 \pm 0.653$ & $1.978 \pm 0.996$ & $2.641 \pm 0.657$ & $0.695 \pm 0.151$ \\
\hline Low & $10.302 \pm 1.172$ & $1.904 \pm 0.934$ & $0.905 \pm 0.233$ & $1.257 \pm 0.41$ & $0.248 \pm 0.156$ \\
\hline \multirow[t]{2}{*}{ Level of contamination } & \multicolumn{5}{|c|}{ Average Concentration of $\mathrm{Pb}(\mathrm{mg} / \mathrm{kg})$} \\
\hline & Soil & Roots & Shoots & Leaves & Fruits \\
\hline Control & $0.161 \pm 0.091$ & $0.303 \pm 0.137$ & $0.09 \pm 0.019$ & $0.283 \pm 0.054$ & $0.161 \pm 0.031$ \\
\hline High & $71.054 \pm 6.698$ & $17.035 \pm 8.33$ & $6.362 \pm 2.138$ & $9.925 \pm 2.568$ & $1.986 \pm 0.694$ \\
\hline Medium & $28.088 \pm 6.297$ & $7.008 \pm 2.283$ & $2.522 \pm 0.511$ & $3.708 \pm 0.319$ & $0.881 \pm 0.410$ \\
\hline Low & $14.302 \pm 5.216$ & $4.087 \pm 2.018$ & $1.681 \pm 0.444$ & $2.566 \pm 0.370$ & $0.530 \pm 0.139$ \\
\hline
\end{tabular}

NA=Not Available 
Table 3: Safe limit of heavy metal concentration in vegetable $(\mathrm{mg} / \mathrm{kg})$.

\begin{tabular}{|llll|}
\hline Metal & Safe limit $^{\mathrm{a}}$ & Safe limit $^{\mathrm{b}}$ & Safe limit $^{\mathrm{c}}$ \\
\hline $\mathrm{Cr}$ & 2.3 & 5 & 0.5 \\
$\mathrm{~Pb}$ & 0.3 & 5 & 9 \\
$\mathrm{Cd}$ & 0.2 & 0.3 & 0.2 \\
$\mathrm{Cu}$ & 73.5 & 40 & 20 \\
\hline
\end{tabular}

${ }^{\mathrm{a}} \mathrm{FAO} / \mathrm{WHO}$ standard (Codex Alimentarious Commission, 2001); ${ }^{\mathrm{b}} \mathrm{FAO} /$ WHO standard (Codex Alimentarious Commission, 1985); ${ }^{\mathrm{c}}$ SEPA (2005)

times higher than the accumulation of $\mathrm{Cr}$. $\mathrm{Pb}$ concentration in shoots and leaves were approximately three times higher than $\mathrm{Cr}$ at a high level of contamination. At this level, no plants grown in $\mathrm{Cr}$ contaminated soil yielded fruits. At the medium level of contamination, the difference between the accumulation of $\mathrm{Cr}$ and $\mathrm{Pb}$ was not so high. In comparison with high levels, accumulations in roots, shoots, leaves, and fruits were close to each other. Roots accumulated two times higher $\mathrm{Pb}$ than $\mathrm{Cr}$ at a low level of contamination. $\mathrm{Pb}$ accumulation in fruits was significantly higher than $\mathrm{Cr}$. Moreover, $\mathrm{Pb}$ exceeded the safe level of $0.3 \mathrm{mg} / \mathrm{kg}$ suggested by FAO/WHO (2001). The accumulation trend of $\mathrm{Pb}$ was root $>$ leaves $>$ shoots, which is completely similar to this study and the order of $\mathrm{Cr}$ accumulation was slightly dissimilar (root $>$ shoots $>$ leaves).

\section{Transfer of Heavy Metals from Contaminated Soil to Different Parts of Chilli Plants}

The transfer factor (TF) of chromium and lead from soil to root, root to shoot, shoot to leaves, and leaves to fruits of chilli plants have been illustrated in Table 4. TF of both $\mathrm{Cr}$ and $\mathrm{Pb}$ for soil to root was the lowest at three levels of contamination. The highest TF values were found in the shoot to leaves because shoots accumulated less concentration of metals than leaves. At a low level of contamination, the transfer factor was higher among different organs of the plants. The $\mathrm{TF}$ values of $\mathrm{Cr}$ maintained the order: leaves $>$ shoots $>$ fruits $>$ roots at every level of contamination. Zayed et al. (1998) reported Cr accumulation in roots and shoots of vegetable plants in various chemical forms such as $\mathrm{Cr}^{3+}$ and $\mathrm{CrO}_{4}{ }^{2-}$ and recommended that roots accumulation was 100 times higher than shoots, which indicates that the translocation from root to shoot is very limited.

The TF values of $\mathrm{Pb}$ were found in the following order: leaves $>$ shoots $>$ roots $>$ fruits at every level of contamination. Transfer factors for leaves to fruits were $0.20,0.23$, and 0.21 for high, medium, and low levels of contamination, respectively. Several studies were conducted to determine the transfer factor (TF) of $\mathrm{Cr}$ and $\mathrm{Pb}$ in various types of plants, especially vegetables. Table 5 illustrates the comparison of TF values of $\mathrm{Cr}$ and $\mathrm{Pb}$ of previous studies and present one. The plants grown on heavy metal contaminated soil, accumulate and transfer $\mathrm{Cr}$ and $\mathrm{Pb}$ from the soil such as metal-scrap dumpsite (Yashim et al. 2014), ferro-alloy manufactory site (Liao et al. 2011), domestic sewage sludge (Jamali et al. 2009) etc. It is evident from the earlier investigations that the TF value of most plants was $<1$, which is analogous to the present study. Leafy vegetables like Red spinach (Basella alba) can translocate a high amount of metals than other plants (Akhtaruzzaman et al. 2013).

\section{Bio-Concentration Factor (BCF)}

The Bioconcentration Factor (BCF) Index symbolizes the capability of the chilli plant to extract heavy metals from the soil. Table 6 illustrates the $\mathrm{BCF}$ of $\mathrm{Cr}$ and $\mathrm{Pb}$ from the soil to the whole chilli plant. However, the highest BCF value was found on a medium level of contamination, which was 0.07 and 0.04 was the lowest value found on a high level of contamination. In every level of contamination, $\mathrm{Pb}$ was higher

Table 4: Transfer factor of $\mathrm{Cr}$ and $\mathrm{Pb}$ from soil to different parts (roots, shoots, leaves, and fruits) of chilli plant.

\begin{tabular}{|lllll|}
\hline Transfer factor (TF) for Cr & \multicolumn{5}{l|}{} \\
\hline Level of contamination & TF for soil to roots & TF for root to shoots & TF for the shoot to leaves & TF for leaves to fruits \\
\hline High & 0.12 & 0.27 & 1.08 & NA \\
Medium & 0.11 & 0.33 & 1.33 & 0.26 \\
Low & 0.18 & 0.47 & 1.39 & 0.20 \\
Mean & 0.14 & 0.36 & 1.27 & 0.23 \\
\hline Transfer factor (TF) for Pb & & & & TF for the shoot to leaves \\
\hline Level of contamination & TF for soil to roots & TF for root to shoots & TF leaves to fruit \\
\hline High & 0.24 & 0.37 & 1.56 & 0.20 \\
Medium & 0.25 & 0.36 & 1.47 & 0.23 \\
Low & 0.29 & 0.41 & 1.52 & 0.21 \\
Mean & 0.26 & 0.38 & 1.52 & 0.21 \\
\hline
\end{tabular}


Table 5: Comparison of transfer factors of $\mathrm{Cr}$ and $\mathrm{Pd}$ of different plant species with the present study.

\begin{tabular}{|c|c|c|c|c|}
\hline \multirow{2}{*}{\multicolumn{2}{|c|}{ Name of the studied plants }} & \multicolumn{2}{|c|}{ Transfer factor (TF): Soil to plants } & \multirow[t]{2}{*}{ References } \\
\hline & & $\mathrm{Cr}$ & $\mathrm{Pb}$ & \\
\hline \multicolumn{2}{|l|}{ Paddy (Oryza sativa) } & 1.97 & 0.29 & Payus et al. (2015) \\
\hline \multicolumn{2}{|l|}{ Red spinach (Basella alba) } & $1.173-3.83$ & $0.695-3.155$ & Akhtaruzzaman et al. (2013) \\
\hline \multicolumn{2}{|l|}{ Spinach (Spinacia oleracea $\mathrm{L}$ ) } & 0.91 & 0.50 & Tiwari et al. (2010) \\
\hline \multirow{2}{*}{\multicolumn{2}{|c|}{ Tomato (Lycopersicon esculentum) }} & 0.009 & 0.008 & Jolly et al. (2013) \\
\hline & & 0.39 & 0.70 & Tiwari et al. (2010) \\
\hline \multicolumn{2}{|l|}{ Cauliflower (Brassica oleracea) } & 0.008 & 0.015 & Jolly et al. (2013) \\
\hline \multicolumn{2}{|l|}{ Celery (Apium graveolens) } & 0.002 & - & Liao et al. (2011) \\
\hline \multicolumn{2}{|l|}{ Lettuce (Lactuca sativa) } & 0.03 & - & Liao et al. (2011) \\
\hline \multirow{3}{*}{\multicolumn{2}{|c|}{ Cabbage (Brassica oleracea) }} & 0.04 & - & Liao et al. (2011) \\
\hline & & - & 0.339 & Radulescu et al. (2013) \\
\hline & & 0.58 & 0.50 & Tiwari et al. (2010) \\
\hline \multicolumn{2}{|l|}{ Orange (Citrus reticulate) } & 0.59 & 0.33 & Mbong et al. (2014) \\
\hline \multirow{2}{*}{\multicolumn{2}{|c|}{ Radish (Raphanus sativus) }} & 0.029 & 0.034 & Jolly et al. (2013) \\
\hline & & 0.58 & 0.70 & Tiwari et al. (2010) \\
\hline \multicolumn{2}{|l|}{ Maize (Zea mays) } & - & 0.166 & Lato et al. (2012) \\
\hline \multirow{2}{*}{\multicolumn{2}{|c|}{ Eggplant (Solanum melongena) }} & - & 1.93 & Yashim et al. (2014) \\
\hline & & 0.63 & 0.60 & Tiwari et al. (2010) \\
\hline \multicolumn{2}{|l|}{ Chilli (Capsicum annum) } & 0.83 & 0.40 & Tiwari et al. (2010) \\
\hline \multirow[t]{3}{*}{ Chilli (Capsicum annum) } & High contamination & 0.21 & 0.50 & \multirow{3}{*}{ Present study } \\
\hline & Medium contamination & 0.36 & 0.50 & \\
\hline & Low contamination & 0.42 & 0.62 & \\
\hline
\end{tabular}

than $\mathrm{Cr}$. BCF values for $\mathrm{Pb}$ are $0.11,0.09$ and 0.10 for high, medium and low levels of contamination, respectively. BCF values $>2$ were considered as high (Blaylock et al. 1997). However, the BCF values were below this limit in the current study. Therefore, it can be concluded that the chilli plant has the lowest capacity to accumulate heavy metals. Mellem et al. (2009) studied on Amaranthus dubius, where they found that $\mathrm{BCF}$ value was higher in $\mathrm{Pb}$ than $\mathrm{Cr}$, which is similar to this study. Both studies show $\mathrm{BCF}$ values $\mathrm{Cr}<\mathrm{Pb}$, although Amaranthus dubius has more phytoextraction capability than Capsicum annuum. The $\mathrm{BCF}$ values of $\mathrm{Pb}$ and $\mathrm{Cr}$ in a variety of vegetables were found within the range of 0.0001-0.0648 and 0.0002-0.027, respectively (Chang et al. 2013).

\section{Daily Intake of Metals (DIM), Health Risk Index and Carcinogenic Risks}

The daily intake of $\mathrm{Cr}$ and $\mathrm{Pb}$, health risk index and carcinogenic risks were estimated for the chilli plants grown in artificially contaminated soils and presented in Table 7. DIM value for $\mathrm{Cr}$ and $\mathrm{Pb}$ was the smallest in all levels of contamination, although chilli is needed in the daily diet in
Bangladesh, usually used as a spice and condiment, thus taken in low quantity. That may be the reason for the lower DIM values for the Chilli plant in this study. Accumulation ability and $\mathrm{DIM}$ values of $\mathrm{Pb}$ in the Chilli plant were higher than $\mathrm{Cr}$.

The DIM values for $\mathrm{Cr}$ and $\mathrm{Pb}$ did not exceed the standard value set by WHO/FAO. Therefore, chilli grown on this soil can be considered completely safe to eat. However, chilli plants grown on highly contaminated soil exceeded the DIM value of WHO/FAO (Likuku \& Obuseng 2015). Cr, Pb and $\mathrm{Zn}$ accumulations were considerably high in green peppers

Table 6: Bioconcentration factor $(\mathrm{BCF})$ of $\mathrm{Cr}$ and $\mathrm{Pb}$ from the soil to the whole chilli plant.

\begin{tabular}{|lll|}
\hline \multirow{2}{*}{ Level of contamination } & \multicolumn{2}{l|}{ Bioconcentration factor $(\mathrm{BCF})$} \\
\cline { 2 - 3 } & $\mathrm{Cr}$ & $\mathrm{Pb}$ \\
\hline High & 0.04 & 0.11 \\
Medium & 0.07 & 0.09 \\
Low & 0.05 & 0.10 \\
\hline
\end{tabular}


Table 7: Daily intake of metals (DIM) and Health risk index of $\mathrm{Cr}$ and $\mathrm{Pb}$ from chilli plant grown on artificially contaminated soil.

\begin{tabular}{|lllllll|}
\hline \multirow{2}{*}{ Level of contamination } & \multicolumn{2}{l}{ Daily Intake of Metals (mg/day) } & \multicolumn{2}{ll}{ Health risk index } & \multicolumn{2}{l|}{ Cancer Risk (CR) } \\
\cline { 2 - 7 } & $\mathrm{Cr}$ & $\mathrm{Pb}$ & $\mathrm{Cr}$ & $\mathrm{Pb}$ & $\mathrm{Cr}$ & $\mathrm{Pb}$ \\
\hline High & $\mathrm{NA}$ & $4.22 \times 10^{-5}$ & $\mathrm{NA}$ & 0.012 & $\mathrm{NA}$ & $3.587 \times 10^{-7}$ \\
Medium & $1.47 \times 10^{-5}$ & $1.87 \times 10^{-5}$ & 0.005 & 0.005 & $6.027 \times 10^{-7}$ & $1.59 \times 10^{-7}$ \\
Low & $0.5 \times 10^{-5}$ & $1.12 \times 10^{-5}$ & 0.017 & 0.003 & $2.05 \times 10^{-7}$ & $9.52 \times 10^{-8}$ \\
WHO/FAO* & $0.05-0.2$ & 0.214 & & & & \\
\hline
\end{tabular}

$\mathrm{NA}=$ Not Available; *WHO/FAO values in $\mathrm{mg} /$ day are based on a $60 \mathrm{~kg}$ body weight adult.

(Capsicum annum L.) as compared to the safe limit of the joint WHO/FAO Food Standards Program Code Alimentarius Commission. The health risk index (HRI) values of $\mathrm{Cr}$ and $\mathrm{Pb}$ were 0.005 and 0.017 for the medium and low levels of contamination, respectively. HRI value was higher in high (0.012) $\mathrm{Pb}$ treatment than medium (0.005) and low (0.003) treatment. In this study, the HRI value was less than 1 , which indicates the consumers were safe. Based on the results of Carcinogenic risks (CR) values in the present study (Table 7), contamination by $\mathrm{Cr}$ and $\mathrm{Pb}$ in Chilli plant can be said safe in terms of carcinogenic risks. According to USEPA (2015), $\mathrm{CR}$ values exceeding $1 \times 10^{-4}$ cause significant cancer risks. However, the $\mathrm{CR}$ values in this study ranged $2.05 \times 10^{-7}$ to $6.027 \times 10^{-7}$ and $1.59 \times 10^{-7}$ to $9.52 \times 10^{-8}$ for $\mathrm{Cr}$ and $\mathrm{Pd}$, respectively although the elevated level of carcinogenic risks posed by $\mathrm{Cr}$ and $\mathrm{Pb}$ were recorded in Centella asiatica and other several varieties of vegetable plants (Ruchuwararak et al. 2018).

\section{CONCLUSIONS}

Heavy metals are considered dreadful pollutants that cause damage to plants as well as human health. The soils adjacent to the industrial area accumulate metals and transfer these to the edible parts of plants. In this study, at a high level of contamination, plants did not yield any fruits. $\mathrm{Cr}$ concentration $(0.695 \pm 0.151 \mathrm{mg} / \mathrm{kg})$ in fruits grown on medium contaminated soil slightly exceeded the safe limit of $0.5 \mathrm{mg} / \mathrm{kg}$. Fruits grown on high $\mathrm{Pb}$ contaminated soil $(1.986 \pm 0.694 \mathrm{mg} / \mathrm{kg})$ exceeded the safe limit of $0.3 \mathrm{mg} / \mathrm{kg}$. Accumulation of $\mathrm{Pb}$ was higher than $\mathrm{Cr}$ in every part of the chilli plants at three levels of contamination. The Transfer Factor (TF) for $\mathrm{Cr}$ has been found in the order of leaves $>$ shoots $>$ fruits $>$ roots, and for $\mathrm{Pb}$ transfer, the order was leaves $>$ shoots $>$ roots $>$ fruits at every level of contamination. Daily Intake of Metals (DIM) for $\mathrm{Cr}$ and $\mathrm{Pb}$ was deficient in all levels of contamination, and it was higher for $\mathrm{Pb}$ than $\mathrm{Cr}$. Therefore, industrial waste containing heavy metals needs treatment before discharging into the environment. Consumption of plants grown in the contaminated area also requires proper pre-treatment.

\section{REFERENCES}

Aktaruzzaman, M., Fakhruddin, A.N.M., Chowdhury, M.A.Z., Fardous, Z. and Alam, M.K. 2013. Accumulation of heavy metals in soil and their transfer to leafy vegetables in the region of Dhaka Aricha highway, Savar, Bangladesh. Pak. J. Biol. Sci., 16: 332-338.

Akintan, O., Olusola, J. and Azeez, A. 2019. Heavy metals loads in soil, farmlands and plant crop at open dumpsite. Global J. Environ. Sci. Manage., 5(4): 449-460.

Allen, S.E., Grimshaw, H.M. and Rowland, A.P. 1986. Chemical analysis. In: Methods in Plant Ecology, Moore PD and SB Chapman (Eds). Blackwell scientific publication, Oxford, London, 285-337.

Aydinalp, C. and Marinova, S. 2009. The effects of heavy metals on seed germination and plant growth on Alfalfa Plant (Medicago sativa). Bulg. J. Agric. Sci., 15(4): 347-350.

BBS 2015. Statistical Yearbook of Bangladesh. Bangladesh Bureau of Statistics, Planning Division, Ministry of Planning, Dhaka, Bangladesh, $1-393$.

Blaylock, M.J., Salt, D.E., Dushenkov, S., Zakharova, O., Gussman, C., Kapulnik, Y., Ensley, B.D. and Raskin, I. 1997. Enhanced accumulation of $\mathrm{Pb}$ in Indian mustard by soil-applied chelating agents. Environ. Sci. Technol., 31(3): 860- 865.

Chang, C.Y., Yu, H.Y., Chen, J.J., Li, F., Zhang, H. and Liu, C. 2014. Accumulation of heavy metals in leaf vegetables from agricultural soils and associated potential health risks in the Pearl River Delta, South China. Environ. Monit. Assess., 186: 1547-1560.

Chowdhury, M.A.Z., Fakhruddin, A.N.M., Islam, M.N., Moniruzzaman, M., Gan, S.H. and Alam, M.D. 2013. Detection of the residues of nineteen pesticides in fresh vegetable samples using gas chromatography massspectrometry. Food Control, 34: 457-465.

Dube, B.K., Tewari, K., Chatterjee, J. and Chatterjee, C. 2003. Excess chromium alters uptake and translocation of certain nutrients in Citrullus. Chemosphere, 53: 1147-1153.

FAO/WHO standards. 1985. Codex Alimentarius Commission (FAO/ WHO): Food Additives and Contaminants, ALINORM 85/15, 1-100.

FAO/WHO standards. 2001. Codex Alimentarius Commission (FAO/ WHO): Food Additives and Contaminants, ALINORM 01/12, 1-197.

Gleason, K., Shine, J.P., Shobnam, N., Rokoff, L.B., Suchanda, H.F., Ibne Hasan, M.O.S., Mostofa, G., Amarasiriwardena, C., Quamruzzaman, Q., Rahman, M., Kile, M.L., Bellinger, D.C., Christiani, D.C., Wright, R.O. and Mazumdar, M. 2014. Contaminated turmeric is a potential source of lead exposure for children in rural Bangladesh. J. Environ. Public Health, Article ID 730636: 1-5

Guertin, J. 2004. Toxicity and health effects of chromium (All Oxidation States). Chromium VI Handbook. CRC Press LLC. 216-230.

Gupta, N., Khan, D.K. and Santra, S.C. 2007. An assessment of heavy metal contamination in vegetables grown in wastewater irrigated areas of Titagarh, West Bengal, India. Bull. Environ. Contam. Toxicol., 80(2): 115-118.

Halim, M.A., Majumder, R.K. and Zaman, M.N. 2014. Paddy soil heavy metal contamination and uptake in rice plants from the adjacent area 
of Barapukuria coal mine, Northwest Bangladesh. Arabian J. Geosci., 8(6): 3391-3401.

Hossain, M.S., Fakhruddin, A.N.M., Chowdhury, M.A.Z., Rahman, M.A. and Khorshed, A. 2015. Health risk assessment of selected pesticide residues in locally produced vegetables of Bangladesh. Int. Food Res J., 22(1): 110-115.

Hung, N.M., Hiep, N.V., Dung, B.N. and Hai, N.X. 2014. Lead accumulation in different parts of okra plant (Abelmoschus esculentus). ARPN. J. Agri. Biol. Sci., 9(6): 190-194.

Iqbal, M.Z., Saeeda, S. and Muhammad, S. 2001. Effects of chromium on an important arid tree (Caesalpinia pulcherrima) of Karachi city, Pakistan. Ekologia Bratislava, 20: 414-422.

Jamali, M.K., Kazi, T.G., Arain, M.B., Afridi, H.I., Jalbani, N., Kandhro, GA. and Baig, J.A. 2009. Heavy metal accumulation in different varieties of wheat (Triticum aestivum $L$.) grown in soil amended with domestic sewage sludge. J. Hazard. Mater., 164: 1386-1391.

Jolly, Y.N., Islam, A. and Akbar, S. 2013. Transfer of metals from soil to vegetables and possible health risk assessment. Springerplus, 2: 385.

Kabir, M.M., Fakhruddin, A.N.M., Chowdhury, M.A.Z., Fardous, Z. and Islam, R. 2017. Characterization of tannery effluents of Hazaribagh area, Dhaka, Bangladesh. Pollution, 3: 395-406.

Kabir, M.M., Fakhruddin, A.N.M., Chowdhury, M.A.Z., Pramanik, M.K. and Fardous, Z. 2018. Isolation and characterization of chromium (VI)-reducing bacteria from tannery effluents and solid wastes. World J. Microbiol. Biotechnol., 34: 126.

Khan, S., Farooq, R., Shahbaz, S., Khan, M.A. and Sadique, M. 2009. Health risk assessment of heavy metals for population via consumption of vegetables. World Applied Sci. J., 6(12): 1602-1606.

Karbassi, A., Tajziehchi, S. and Khoshgalb, H. 2018. Speciation of heavy metals in coastal water of Qeshm Island in the Persian Gulf. Global J. Environ. Sci. Manage., 4(1): 91-98.

Lato, A., Radulov, I., Berbecea, A., Lato, K. and Crista, F. 2012.The transfer factor of metals in soil-plant system. Res. J. Agri Sci., 44(3): $67-72$

Lawrence, H.S. and Borkowsky, W. 1983. A new basis for the immuno regulatory activities of transfer factor--an arcane dialect in the language of cells. Cell. Immunol., 82 (1): 102-116.

Liao, Y., Wang, Z., Yang, Z., Chai, L., Chen, J. and Yuan, P. 2011. Migration and transfer of chromium in soil-vegetable system and associated health risks in vicinity of ferro-alloy manufactory. T. Nonferr. Metal Soc. Chin., 21(11): 2520-2527.

Likuku, A.S. and Obuseng, G. 2015. Health risk assessment of heavy metals via dietary intake of vegetables irrigated with treated wastewater around Gaborone, Botswana. International Conference on Plant, Marine and Environmental Sciences, 1(2): 32-37.

Lima, F.S., Nascimento, C.W., Silva, F.B., Carvalho, V.G. and Filho, M.R. 2009. Lead concentration and allocation in vegetable crops grown in a soil contaminated by battery residues. Hortic. Bras., 27: 362-365.

Mackay, D. 1982. Correlation of bioconcentration factors. Environ. Sci. Technol., 16: 274-278.

Mbong, E.O., Akpan, E.E. and Osu, S.R. 2014. Soil-plant heavy metal relations and transfer factor index of habitats densely distributed with Citrus reticulata (tangerine). J. Res. Environ. Sci. Toxicol., 3(4): 61-65.

Mellem, J.J., Bajinath, H. and Odhav, B. 2009. Translocation and accumulation of $\mathrm{Cr}, \mathrm{Hg}, \mathrm{As}, \mathrm{Pb}, \mathrm{Cu}$, and $\mathrm{Ni}$ by Amaranthus dubius
(Amaranthaceae) from contaminated Sites. J. Environ. Sci. Health Part A, 44: 568-575.

Naser, H.M., Sultana, S., Gomes, R. and Noor, S. 2012. Heavy metal pollution of soil and vegetable grown near roadside at Gazipur, Bangladesh. J. Agri. Res., 37(1): 9-17.

Pandey, N. and Sharma, C.P. 2002. Effect of heavy metals $\mathrm{CO}^{+2}, \mathrm{Ni}^{+2}$, and $\mathrm{Cd}^{+2}$ on growth and metabolism of cabbage. Plant Sci., 163: 753-758.

Ruchuwararak, P., Intama, S., Tengjaroenkul, B. and Neeratanaphan, L. 2018. Bioaccumulation of heavy metals in local edible plants near a municipal landfill and the related human health risk assessment. Hum. Ecol. Risk Assess., 25(7): 1760-1772.

Payus, C., Talip, A.F.A. and Hsiang, T.W. 2015. Heavy metals accumulation in paddy cultivation area of Kompipinan, Papar district, Sabah. J. Sust. Sci. Manag., 10(1): 76-86.

Proshad, R., Kormoker, T., Islam, M.S. and Chandra, K. 2019. Potential health risk of heavy metals via consumption of rice and vegetables grown in the industrial areas of Bangladesh. Hum. Ecol. Risk. Assess., 26(4): 921-943.

Radulescu, C., Stihi, C., Popescu, IV., Dulama, I.D., Chelarescu, E.D. and Chilian, A. 2013. Heavy metal accumulation and translocation in different parts of Brassica oleracea L. Rom. Journ. Phys., 58(910): 1337-1354

Sarma, H., Deka, S., Deka, H. and Saikia, R.R. 2011. Accumulation of heavy metals in selected medicinal plants. Rev. Environ. Contam. T., 214: 63-86.

Shaheen, N., Irfan, N. and Khan, I.N. 2016. Presence of heavy metals in fruits and vegetables: health risk implications in Bangladesh. Chemosphere, 152: 431-438.

SEPA, 2005. The limits of Pollutants in Food. China: State Environmental Protection Administration, GB2762-2005.

Singh, H.P., Mahajan, P., Kaur, S. and Kohli, R. 2013. Chromium toxicity and tolerance in plants. Environ. Chem. Letters., 11(3): 229-254.

Singh, S., Zacharias, M., Kalpana, S. and Mishra, S. 2012. Heavy metals accumulation and distribution pattern in different vegetable crops. J. Environ. Chem. Ecotoxicology, 4(10): 170-177.

Tiwari, K.K., Singh, N.K., Patel, M.P., Tiwari, M.R. and Rai, U.N. 2011. Metal contamination of soil and translocation in vegetables growing under industrial wastewater irrigated agricultural field of Vadodara, Gujarat, India. Ecotoxicol. Environ., Safe., 74: 1670-1677.

Tsafe, A.I., Hassan, L.G., Sahabi, D.M., Alhassan, Y. and Bala, B.M. 2012. Evaluation of heavy metals uptake and risk assessment of vegetables grown in Yargalma of Northern Nigeria. J. Basic Appl. Sci. Res., 2(7): 6708-6714.

USEPA (US Environmental Protection Agency). 2015. Risk based screening table. Composite Table: Summary Tab 0615.

USEPA (US Environmental Protection Agency) 2017. Regional Screening Level (RSL) Summary Table (TR=1E-06, HQ=1).

World Health Organization (WHO) 1993. Evaluation of Certain Food Additives and Contaminants. In: Forty-First Report of the Joint FAO/ WHO Expert Committee on food additives. 1-223.

Yashim, Z.I., Israel, O.K. and Hannatu, M. 2014. A study of the uptake of heavy metals by plants near metal-scrap dumpsite in Zaria, Nigeria. J. Appl. Chem., Article ID 394650.

Zayed, A., Mel Lytle, C. Qian, J. and Terry, N. 1998. Chromium accumulation, translocation, and chemical speciation in vegetable crops. Planta, 206: 293-299. 